\title{
Prototype Mesin Pengantar Barang Otomatis Menggunakan Load Cell Berbasis Robot Line Follower
}

\author{
Dwi Budi Susilo ${ }^{1}$, Hari Wibawanto ${ }^{2}$, dan Anggraini Mulwinda ${ }^{3}$ \\ Jurusan Teknik Elektro, Fakultas Teknik, Universitas Negeri Semarang \\ Kampus Sekaran, Gunungpati, Semarang, 50229, Indonesia

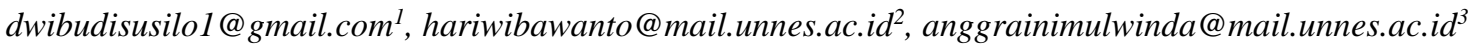

\begin{abstract}
Overloaded condition in the product porter like hand pallet, hand stacker, forclift, and etc, can causes damage and terrible accident in the machine operator. This research aim to build a prototype of porter machine that can prevent overloaded condition through the reading of load cell and photo diode sensor to guide the line follower direction. Research and development methods are used with the systematic writing are background of study and problems, prototype design and validation, testing, taking and analysis of the data. Output of the research is a prototype of porter machine using load cell sensor based on line follower robot. The Result of the load cell reading is compared to SF-400 weigher, and found the difference amount $0.117 \%$. The load testing data of automatic moving trigger is 1 gram until 2999 gram. The Overload condition warning is active while the load is more than 3000 gram. The data reading of the photo diode on the black line is running succesfully, however on the white line with orange color is found some error.
\end{abstract}

Keywords-Prototype, line follower, load cell, foto dioda

\begin{abstract}
Abstrak- Beban angkut berlebih pada alat pegangkut barang seperti hand pallet, hand stacker, forklift, dan produk lainya dapat mengakibatkan kerusakan dan kecelakaan operator mesin. Tujuan penelitian ini adalah menghasilkan prototype mesin pengantar barang yang mampu mencegah mesin beroperasi dengan beban berlebih dengan mengetahui hasil pembacaan load cell dan sensor foto dioda untuk pemandu arah line follower. Metode penelitian dan pengembangan digunakan untuk penelitian ini dengan tahapan pengembangan potensi dan perumusan masalah, perencanaan desain alat, validasi desain, uji coba alat, pengambilan data dan analisis data penelitian. Hasil yang diperoleh berupa prototype mesin pengantar barang menggunakan load cell berbasis robot line follower, dengan hasil uji pembacaan load cell terhadap timbangan pembanding SF400 didapatkan perbedaan $0,117 \%$. Data uji beban picu gerak otomatis prototype mampu dipicu beban terkecil 1 gram sampai 2999 gram. Peringatan over load terjadi saat beban melebihi 3000 gram. Data pembacaan foto dioda pada uji coba garis warna putih terdapat error pada variasi warna dasar oranye cerah sedangkan pada garis warna hitam tidak terjadi error.
\end{abstract}

Kata kunci-Prototype, line follower, load cell, foto dioda

\section{PENDAhUluan}

Dalam dunia industri, teknologi robotika telah diimplementasikan pada mesin-mesin industri. Teknologi robotika dipilih karena beberapa keunggulan diantaranya yaitu cepat, teliti, mampu bekerja secara full time dan otomatis. Berdasarkan PERMENPRIN [1], restrukturisasi mesin dan/ atau peralatan industri kecil dan menengah yang selanjutnya disebut restrukturisasi adalah penggantian dan/ atau penambahan mesin dan/ atau peralatan produksi industri kecil dan industri menengah yang lebih efisien dan produktif untuk menghasilkan produk bermutu dan berdaya saing. Mesin industri adalah mesin yang dipergunakan industri baik dalam proses produksi maupun distribusi sedangkan mesin distribusi adalah mesin angkut dan angkat barang yang dipergunakan pada proses distribusi.

Saluran distribusi adalah serangkaian organisasi yang saling tergantung yang terlibat dalam proses untuk menjadikan barang atau jasa siap untuk digunakan atau dikonsumsi, anggota saluran distribusi perlu memperhatikan keputusan pengangkutan [2]. Pilihan pengangkutan akan mempengaruhi penetapan harga produk, kinerja pengiriman tepat waktu dan kondisi barang saat tiba di tujuan, semua itu akan mempengaruhi kepuasaan pelanggan.

Pentingnya alat pengangkut dalam proses distribusi mendorong para produsen mesin angkut untuk membuat berbagai macam produk alat pegangkut beban seperti hand pallet, hand stacker, forklift, dan produk-produk lainya agar dapat memenuhi permintaan pasar dalam berbagai kebutuhan pengangkutan barang. Namun sering kali masalah muncul terkait penggunaan alat tersebut seperti kerusakan alat akibat kelebihan beban angkut. Besarnya kapasitas angkut pada industri mengakibatkan bermacam-macam jenis kerusakan alat pengangkut baik kerusakan mesin pada sistem mekanik maupun elektrik. Hasil dari penelitian tentang perawatan alat forklift 5 ton (Studi Kasus PT. Trikarya Alam) [3] kerusakan 
yang terjadi meliputi kebengkokan dan keausan pada crankshaft, bearing, connecting rod, piston, line, oring, intake, dan exhaus valve. Berdasarkan hasil tersebut kerusakan yang terjadi pada alat angkat secara umum adalah kerusakan mekanik akibat umur alat dan beban yang diangkut.

Selain kerusakan mekanik, kelebihan beban juga sering mengakibatkan terjadinya kecelakaan dalam proses pengangkutan barang. Oleh sebab itu pemerintah mengeluarkan peraturan [4] tentang pesawat angkat dan angkut bahwa dalam pemakai bobot imbang harus diketahui secara jelas tentang berat muatan dan posisi bobot imbang tersebut. Maka dari itu perlu adanya alat ukur beban atau timbangan yang memberikan peringatan dan menghentikan gerakan mesin secara otomatis ketika beban berlebihan untuk mencegah terjadinya kecelakaan.

Untuk meminimalisir kecelakaan operator selain penggunaan alat ukur beban untuk mengetahui berat beban secara pasti dan mencegah over load juga dapat dilakukan dengan membuat sistem otomatis pada alat pengangkut barang. Dengan kata lain penggunaan mesin otomatis mengurangi kontak langsung operator dengan mesin sehingga dapat mengurangi kecelakaan [5]. Untuk itu dibutuhkan konversi antara besaran fisik (bobot) menjadi sinyal untuk masukan sistem otomatis.

Sensor load cell merupakan transduser elektronik yang dapat mengubah besaran fisik menjadi sinyal elektrik [6]. Dalam penelitian [7] load cell digunakan sebagai sensor dalam pembuatan timbangan digital yang hasilnya dalam penelitian tersebut produk timbangan digital memiliki tingkat kelayakan $73,95 \%$ dengan standar minimal $60 \%$. Namun pada penelitian ini load cell diterapkan hanya sebagai alat ukur beban sedangkan pada pembatan sisem prototype mesin pengantar barang load cell selain sebagai sensor berat beban juga digunakan sebagai sensor pemicu gerak otomatis.

Selain menggunakan load cell sebagai sensor beban prototype ini juga bekerja secara otomatis menggunakan prinsip kerja robot line follower. Robot line follower merupakan sebuah robot sederhana yang dapat mendeteksi dan mengikuti (follows) sebuah lintasan yang berbentuk sebuah garis (line) [8]. Dalam penelitian sebelumnya line follower digunakan sebagai alat transportasi yang bekerja secara otomatis yang bekerja berdasakan lintasan yang berupa garis [9], [10]. Sedangkan pada pembuatan prototype ini line follower digunakan sebagai alat angkut benda yang terintegrasi dengan alat ukur beban sehingga mampu mengantisipasi kelebihan beban angkut dan bergerak otomatis pada setting beban yang ditentukan.

Pada umumnya robot line follower hanya berjalan pada garis warna hitam dan lantai warna putih atau sebaliknya namun jika diterapkan pada mesin pengantar barang tentu harus lebih adaptif terhadap perubahan warna lantai. Oleh sebab itu tujuan penelitian ini adalah membuat dan meneliti prototype mesin penganatar barang otomatis menggunakan load cell berbasis robot line follower yang berfokus pada penggunaan sensor load cell sebagai alat ukur beban dan foto dioda yang mampu mendeteksi garis pada warna yang berbeda.

\section{Metode PENELITIAN}

Secara umum robot line follower memiliki tiga bagian utama yaitu sensor (masukan), processor (pengolah), dan motor control (keluaran) [11]. Sensor pada line follower terdiri dari dua komponen utama yaitu Light Emitting Diode (LED) dan foto diode. Pada robot line follower sensor foto dioda digunakan sebagai pendeteksi garis [12]. Pada sistem ini ditambahkan sensor load cell sebagai penghitung berat beban dan pemicu gerak otomatis. Diagram blok sistem secara lengkap ditunjukkan pada Gambar 1.

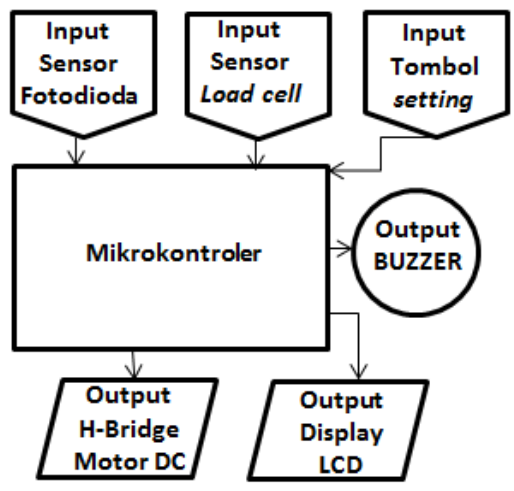

Gambar 1. Diagram sistem prototype

Input foto dioda dipasang pada kondisi bias-reverse agar nilai resistansinya dapat berubah jika terkena pantulan cahaya. Apabila pantulan cahaya yang diterima banyak maka nilai resistasinya akan mengecil sedangkan jika pantulan cahaya sedikit maka nilai resitansinya menjadi besar. Agar dapat diproses, nilai perubahan resistansinya diubah terlebih dahulu menjadi sinyal tegangan. Desain skematik pemasangan foto dioda ditunjukkan pada Gambar 2.

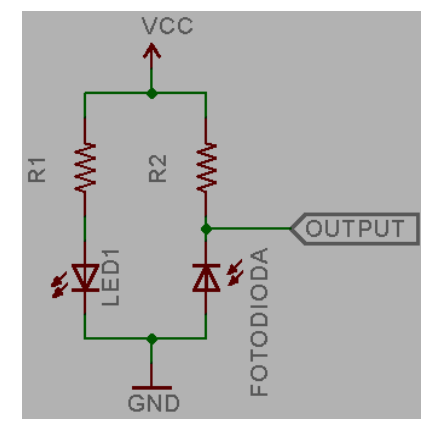

Gambar 2. Rangkaian sensor foto dioda

Load cell merupakan transduser elektronik yang dapat mengubah besaran fisik menjadi sinyal elektrik. Prinsip kerja load cell adalah mengubah gaya tekan beban menjadi nilai perubahan resistan $(\mathrm{R})$. Perubahan resistansi tersebut diolah pada rangkaian jembatan modul HX711. Prinsip kerja elektronik rangkaian jembatan Strain Gauge HX711 adalah mengkonversi perubahan yang terukur dalam perubahan resistansi dan mengkonversinya ke dalam besaran tegangan melalui rangkaian yang ada [13]. Prinsip kerja rangkaian jembatan Strain Gauge ditunjukkan pada Gambar 3. 


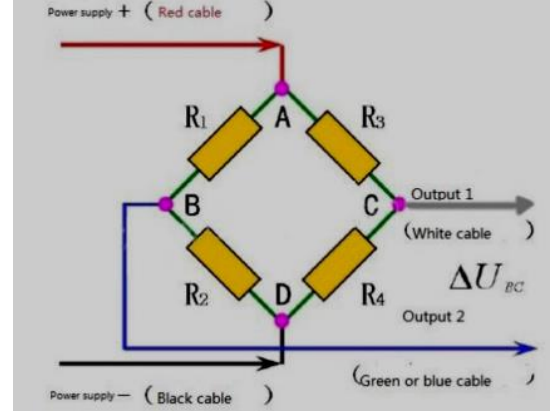

Gambar 3. Prinsip kerja rangkaian jembatan Strain Gauge [13]

Input tombol dirangkai dengan jenis tombol push button dengan resistor pull-up tujuanya adalah agar mampu memberikan input HIGH mendekati 5 Volt dan LOW pada 0 Volt. Desain rangkaian input tombol ditunjukkan pada Gambar 4.

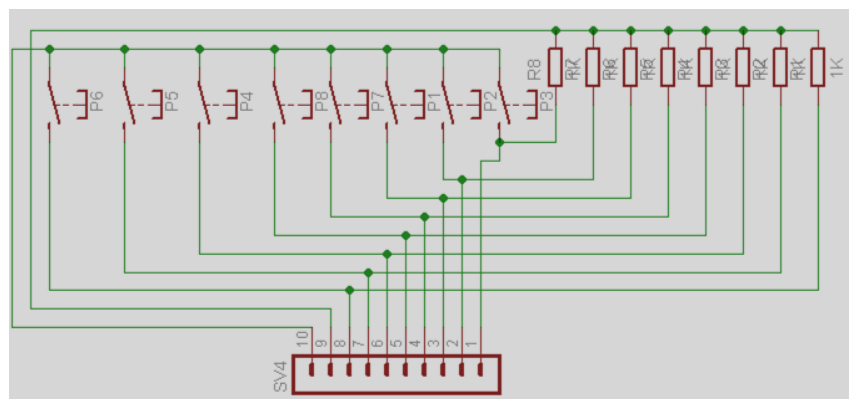

Gambar 4. Desain rangkaian tombol

Pengolahan input dapat mengunakan mikrokontroler atau mikroprosesor, pada prototype ini menggunakan mikrokontroler ATmega32 yang di-bootload arduino. Arduino adalah sebuah board mikrokontroler yang bersifat open source sehingga kita dapat melakukan memodifikasi board arduino dengan menggunakan chip atau IC mikrokontroler Atmel AVR dengan terlebih dahulu mengisinya dengan bootloader [14]. Desain sistem minimum ditunjukkan pada Gambar 5.

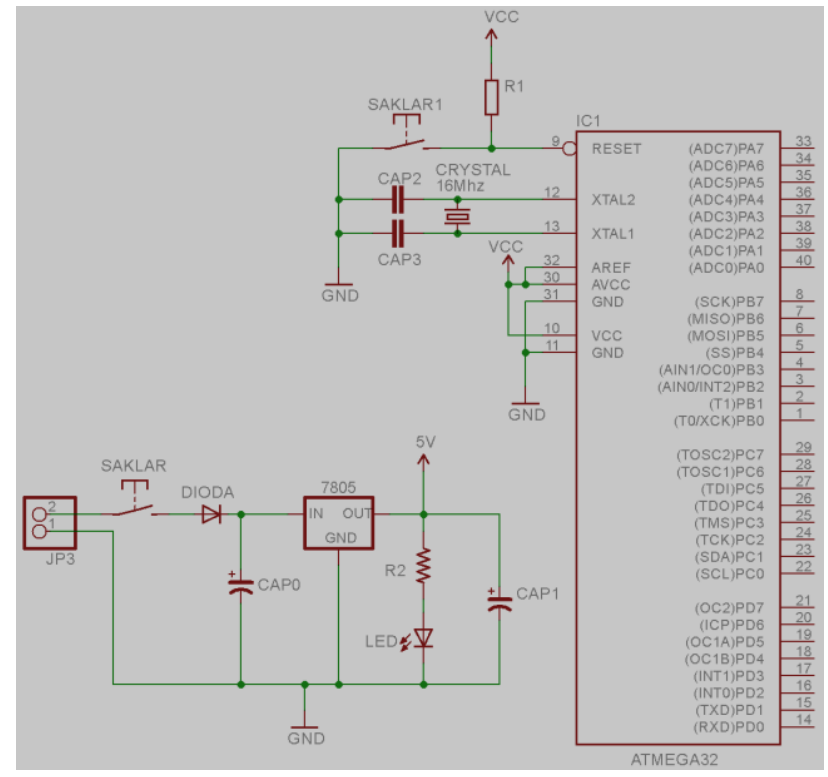

Gambar 5. Desain sistem minimum
Driver motor H-bridge merupakan rangkaian elektronik yang dapat mengontrol motor DC [15]. Pada pembuatan prototype ini menggunakan modul driver motor DC monster motto shield. Monster motto shield terdiri dari sepasang IC dengan tipe VNH2SP30-E. IC tipe VNH2SP30-E adalah IC driver jembatan penuh yang biasa digunakan untuk berbagai keperluan penggerak motor dengan arus maksimum hingga $30 \mathrm{~A}$ dan tegangan maksimum $41 \mathrm{~V}$ [16]. Bentuk fisik monster motto shield ditunjukkan pada Gambar 6.

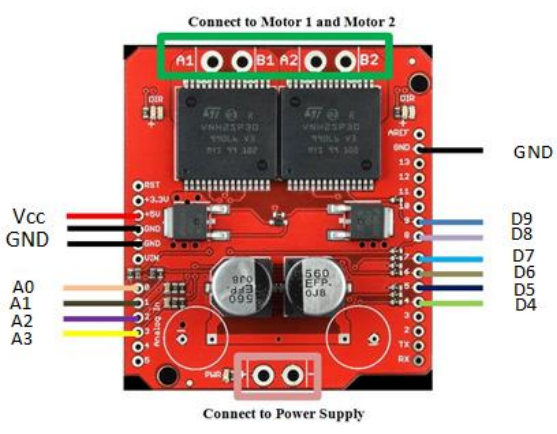

Gambar 6. Ardumoto Monster Motto Shield [16]

Desain alat dibuat dengan menggunakan software SketchUp 2015. Gambar 7 adalah desain alat beserta dimensi prototype mesin pengantar barang otomatis menggunakan load cell berbasis robot line follower.

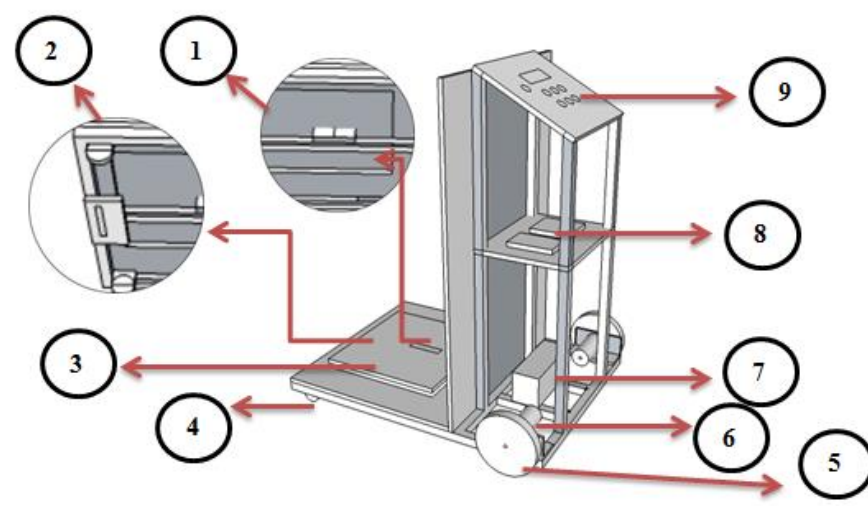

Keterangan:

1. Load cell

2. Sensor

6. Motor

7. Baterai

3. Papan timbangan 8. Papan letak elektronik

4. Roda depan

5. Roda belakang

9. Tampilan dan tombol

\section{Gambar 7. Desain mekanik}

Prototype mesin pengantar barang ini dapat dioperasikan dalam dua mode yaitu mode otomatis dan mode manual. Pada saat mode manual, prototype akan bergerak mengantarkan barang setelah menekan tombol "OKE" sedangkan pada saat mode otomatis, prototype mendeteksi berat beban, apabila melebihi setting beban maka akan bergerak mengantarkan barang menuju titik finish dan setelah barang diambil prototype akan bergerak kembali lagi ke posisi awal (titik start). Lintasan prototipe dibuat dengan garis selebar $3,7 \mathrm{~cm}$ posisi titik start dan finish dibuat dengan gambar bidang datar dengan luas $15 \mathrm{~cm}^{2}$. Contoh lintasan ditunjukkan pada Gambar 8 . 


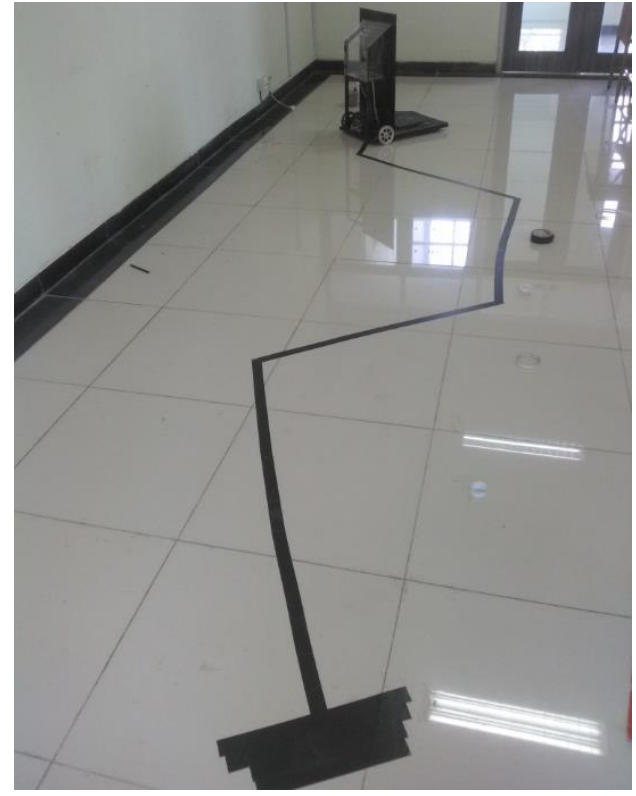

Gambar 8. Contoh lintasan prototype

Sebelum uji penggunaan prototype perlu dilakukan kalibrasi warna garis. Langkah-langkah kalibrasinya sebagai beikut:

- Tekan tombol "MENU”.

- Tekan tombol "UP" atau "DOWN" untuk mencari sub menu kalibrasi hingga ditemukan sub menu KALIBRASI.

- Tekan tombol "OKE" hingga muncul pertanyaan konfirmasi "kalibrasi?" kemudian tekan "OKE" untuk melanjukan atau "CANCEL" untuk membatalkan kalibrasi.

- Tekan tombol "OKE" kemudian geser bagian sensor foto dioda ke kanan dan ke kiri melintasi garis sebanyak lebih dari tiga kali atau lebih.

- Tekan tombol "OKE" untuk menyimpan hasil kalibrasi.

Setelah melalui tahap kalibrasi sensor foto dioda maka protoype siap untuk diuji penggunaan baik otomatis ataupun manual. Untuk uji penggunaan manual dilakukan dengan cara sebagai berikut:

- Letakkan prototype pada lintasan.

- Tekan tombol "MODE" pilih mode manual.

- Letakkan beban dengan berat kurang dari $3 \mathrm{Kg}$ kemudian tekan tombol "OKE".

- Prototype bergerak pada lintasan hingga finish.

- Pengujian ke-dua letakan beban melebihi $3 \mathrm{Kg}$ kemudian tekan tombol "OKE".

- Terdengar bunyi buzzer dan LCD tampil tulisan peringatan "BEBAN TERLALU BERAT".

Untuk uji penggunaan manual dilakukan dengan cara sebagai berikut:

- Tekan tombol "MODE" pilih mode otomatis.

- Lakukan setting berat beban picu gerak otomatis.

- Letakan beban dengan berat di atas SET BEBAN dan kurang dari berat maksimum $3 \mathrm{Kg}$.

- Tekan tombol "OKE".

- Prototype akan bergerak menuju finish dan behenti, setelah barang yang dihantarkan diambil prototype akan bergerak kembali ke start.

- Pengujian ke-dua letakan beban melebihi $3 \mathrm{~kg}$ kemudian tekan tombol "OKE".

- Terdengar bunyi buzzer dan LCD tampil tulisan peringatan "BEBAN TERLALU BERAT".

\section{HASIL DAN PEMBAHASAN}

A. Hasil

\section{1) Pengujian Pembacaan Sensor Load Cell}

Pengujian sensor load cell dilakukan untuk menentukan tingkat keakurasian pembacaan sensor terhadap berat benda serta persentase nilai kesalahan (error) yang terjadi pada alat timbang digital yang dibuat. Pada sistem pengujian sensor load cell dilakukan dengan cara membandingkan hasil pembacaan sensor dengan timbangan digital tipe SF-400 yang sudah dijual tersebar luas di pasaran. Timbangan digital tipe SF-400 adalah jenis timbangan digital dengan sensor strain gauge yang memiliki tingkat ketelitian 1 gram. Hasil pengujian pembacaan sensor load cell ditunjukkan pada Tabel I.

TABEL I. Hasil Pengujian PembacAan LOAD CELL

\begin{tabular}{|c|c|c|c|c|c|c|c|}
\hline \multirow{2}{*}{$\begin{array}{c}\text { Timbangan } \\
\text { pembanding } \\
\text { X (gr) } \\
\end{array}$} & \multicolumn{5}{|c|}{ Hasil pengukuran loadcell (gr) } & \multirow[b]{2}{*}{$\begin{array}{c}\text { Rata-rata kesalahan, } \\
\text { S (gram) }\end{array}$} & \multirow[b]{2}{*}{$\begin{array}{c}\text { Tingkat } \\
\text { kesalahan (error) }\end{array}$} \\
\hline & $\begin{array}{c}1 \\
\text { Y1 (gr) }\end{array}$ & $\begin{array}{c}2 \\
\mathrm{Y} 2 \text { (gr) }\end{array}$ & $\begin{array}{c}3 \\
\text { Y3 (gr) }\end{array}$ & $\begin{array}{c}4 \\
\text { Y4 (gr) }\end{array}$ & $\begin{array}{c}5 \\
\text { Y5 (gr) }\end{array}$ & & \\
\hline 0 & 0 & 0 & 0 & 0 & 0 & 0 & 0 \\
\hline 50 & 50 & 49 & 49 & 50 & 50 & 0,4 & 0,8 \\
\hline 100 & 100 & 99 & 100 & 99 & 101 & 0,2 & 0,2 \\
\hline 200 & 200 & 199 & 201 & 201 & 200 & $-0,2$ & $-0,1$ \\
\hline 250 & 250 & 249 & 252 & 251 & 252 & $-0,8$ & $-0,32$ \\
\hline 500 & 500 & 502 & 504 & 501 & 500 & $-1,4$ & $-0,28$ \\
\hline 1000 & 1002 & 1007 & 1000 & 1003 & 1001 & $-2,6$ & $-0,26$ \\
\hline 1500 & 1506 & 1510 & 1500 & 1511 & 1508 & -7 & $-0,46$ \\
\hline 2000 & 2002 & 2013 & 2009 & 2000 & 2015 & $-7,8$ & $-0,39$ \\
\hline 3000 & 3020 & 3003 & 3016 & 2013 & 3012 & $-10,8$ & $-0,36$ \\
\hline \multicolumn{7}{|c|}{ Rata- rata tingkat kesalahan } & $-1,17$ \\
\hline
\end{tabular}


Berikut cara menghitung rata-rata presentase tingkat kesalahan:

$$
|\bar{E}|=\left|\frac{\sum E}{X}\right|=\left|\frac{-1,17}{10}\right|=0,117 \%
$$

Keterangan:

$|\bar{E}|=$ Rata-rata tingat kesalahan

$\sum E=$ Jumlah selisih kesalahan

$\mathrm{X}=$ Jumlah pengukuran

Data rerata pengukuran berulang dari pembacaan load cell didapatkan -1,17 sehingga persentase penyimpangan kesalahan pengukurannya adalah $0,117 \%$. Perbedaan atau selisih dari pengukuran tersebut terjadi disebabkan oleh beberapa faktor di antaranya adanya tegangan offset dan noise pada pengukuran rangkaian pengkondisi sinyal serta desain mekanik yang hanya terdiri dari satu sensor atau juga dimungkinkan kesalahan yang terjadi disebabkan oleh tingkat ketelitian timbangan pembanding SF-400 yang memiliki nilai ketelitian 1 gram.

2) Pengujian Beban Picu Gerak Otomatis dan Over Load Beban

Pada penelitian ini prototype mesin pengantar barang menggunakan load cell berbasis robot line follower dibuat untuk dapat bergerak mode otomatis dan manual. Mode manual adalah cara mengoperasikan dengan menekan tombol "OKE" secara manual agar prototype mesin atau robot ini dapat bergerak. Sedangkan mode otomatis prototype mesin atau robot ini dapat mendeteksi berat muatan tertentu yang di setting sebelumnya melalui menu SET BEBAN. Hasil pengujian ditunjukkan pada Tabel II.

TABEL II. HASIL Pengujian Beban Picu GeraK Otomatis dan OVER LOAD BEBAN

\begin{tabular}{|c|c|c|c|c|}
\hline \multirow[b]{2}{*}{$\begin{array}{c}\text { Set } \\
\text { Beban } \\
\text { (gram) }\end{array}$} & \multirow{2}{*}{$\begin{array}{c}\text { Hasil } \\
\text { Pembacaan } \\
\text { Timbangan } \\
\text { Pembanding } \\
\text { (gram) }\end{array}$} & \multirow[b]{2}{*}{$\begin{array}{c}\text { Hasil } \\
\text { Pembacaan } \\
\text { Load Cell } \\
\text { (gram) }\end{array}$} & \multicolumn{2}{|c|}{ Keterangan } \\
\hline & & & $\begin{array}{c}\text { Pemicu } \\
\text { Gerak } \\
\text { Otomatis }\end{array}$ & $\begin{array}{c}\text { Overload } \\
\text { Beban }\end{array}$ \\
\hline 1 & 1 & 1 & $\sqrt{ }$ & $\mathrm{X}$ \\
\hline 5 & 5 & 5 & $\sqrt{ }$ & $\mathrm{X}$ \\
\hline 10 & 10 & 10 & $\sqrt{ }$ & $\mathrm{X}$ \\
\hline 100 & 100 & 100 & $\sqrt{ }$ & $X$ \\
\hline 500 & 500 & 500 & $\sqrt{ }$ & $\mathrm{X}$ \\
\hline 1000 & 1000 & 1000 & $\sqrt{ }$ & $\mathrm{X}$ \\
\hline 2000 & 1998 & 2000 & $\sqrt{ }$ & $X$ \\
\hline 2999 & 2985 & 2999 & $\sqrt{ }$ & $\mathrm{X}$ \\
\hline 3000 & 2988 & 3000 & $\mathrm{X}$ & $\sqrt{ }$ \\
\hline 3001 & 2990 & 3001 & $\mathrm{X}$ & $\sqrt{ }$ \\
\hline
\end{tabular}

*)Timbangan pembanding menggunakan timbangan tipe SF-400 dengan beban maksimal $10 \mathrm{Kg}$ dan ketelitian 1 gram

*)Kolom keterangan jika "bekerja" diberikan tanda $(\sqrt{ })$ jika "tidak" maka diberi tanda (x)

Hasil uji coba pengoperasian prototype mesin pengantar barang menunjukan bahwa prototype pengantar barang mampu mengukur berat beban dan memberikan tindakan sesuai program yang ditanamkan dalam mikrokontroler ATmega32. Program yang ditanamkan saat prototype pada mode otomatis memberikan perintah yaitu jika berat beban melebihi atau sama dengan setting beban dan kurang dari berat maksimum maka terjadi delay untuk memastikan posisi beban sudah siap kemudian motor akan bergerak. Namun apabila berat beban lebih dari berat maksimum maka motor tidak akan bergerak dan buzzer peringatan akan berbunyi.

Pada penelitian ini beban maksimum ditentukan $3 \mathrm{Kg}$ dengan hasil yang diperoleh prototype mampu bekerja mulai setting beban terkecil 1 gram sampai dengan 2999 gram dan peringatan over load terjadi saat beban 3000 gram keatas. Akan tetapi terjadi perbedaan penampilan berat beban antara beban terukur pada prototype dengan beban terukur pada timbangan pembanding SF-400 yaitu saat beban yang terukurpada prototype 2000 gram beban terukur pada timbangan pembanding 1998 gram, saat beban yang terukur pada prototype 2999 gram beban terukur pada timbangan pembanding 2985 gram, saat beban yang terukur pada prototype 3000 gram beban terukur pada timbangan pembanding 2988 gram dan saat beban yang terukur pada prototype 3001 gram beban terukur pada timbangan pembanding 2990 gram. Simpangan data hasil uji coba tersebut sejalan dengan simpangan hasil pengujian sensor load cell yaitu $0,117 \%$ terhadap timbangan pembanding SF-400.

\section{3) Pengujian Pembacaan Sensor Foto Dioda}

Dari rangkaian foto dioda yang telah dibuat apa bila sensor berada pada bidang pantul warna putih maka output tegangan akan mendekati 0 Volt dan apabila berada pada bidang pantul warna hitam maka out put tegangan akan mendekati 5 Volt. Kemudian output tegangan tersebut akan diolah ATmega32 dengan analog to digital converter (ADC) 8 bit atau dengan kata lain range tegangan 0 Volt -5 Volt akan dirubah pada bilangan desimal 0-256 agar dapat diolah secara digital oleh mikrokontroler ATmega32 untuk membedakan warna garis terhadap warna dasar. Agar dapat membedakan garis (membacar garis) perlu melakukan kalibrasi sebelum pengoperasian prototype. Kode program yang digunakan saat kalibrasi adalah mencari titik tengah dari selisih data ADC warna garis dan ADC warna dasar atau lantai, apabila pembacaan ADC lebih dari titik tengah maka hasilnya 1 dan jika di bawah titik tengah maka hasilnya 0 . Pada penelitian ini warna yang digunakan menggunkan warna dari kertas asturo dengan tujuan warna yang digunakan standar atau tidak berubah-ubah jika dibandingkan dengan warna hasil print.

Data ADC diambil dari uji coba menggunakan garis hitam dengan melakukan variasi warna dasar dan garis putih dengan melakukan variasi warna dasar. Pada uji coba garis warna putih dengan melakukan variasi warna dasar terdapat error pada warna oranye cerah. ADC yang dihasilkan dari warna putih dari sensor 1 sampai sensor 8 bertutur-turut $11,10,10,10,11,10$, 11 sedangkan warna oranye cerah berturut-turut 48, 24, 31, 23, $33,47,38$ sehingga selisih ADC antara garis hitam dan warna dasar putih $37,14,21,13,23,36,28,44$. Error yang terjadi adalah pada sensor ke-2 dan sensor ke-4 yang memiliki selisih ADC paling sedikit yaitu 14 dan 13 .

Sedangkan pada uji coba garis warna hitam dengan melakukan variasi pada warna dasarnya tidak terjadi error sama sekali meskipun pada selisih ADC terkecil yaitu pada warna coklat tua. ADC warna hitam dari sensor ke-1 sampai sensor ke-8 berturut-turut 223, 225, 222, 223, 221, 224, 223, dan 223 sedangkan ADC warna cokelat tua 200, 198, 199, 198, 
201, 203, 202, dan 202 sehingga selisihnya 23, 27, 23, 25, 20, 21,21 , dan 21 . Hasilnya tidak terjadi error pada penggunaan garis warna hitam dengan melakukan variasi pada warna dasar, hal ini mungkin terjadi karena selisih terkecil dari data ADC adalah 21. Penelitian ini tidak dilanjutkan dengan warna yang lebih gelap mendekati hitam dikarenakan kertas asturo di pasaran yang gelap mendekati hitam hanya sampai di warna cokelat tua.

\section{B. Pembahasan}

Prototype Mesin Pengantar Barang Otomatis menggunakan load cell berbasis robot line follower adalah prototype mesin yang akan membantu proses pengangkutan barang dan bekerja secara semi otomatis. Pengembangan alat ini meliputi otomatisasi kerja alat, pencegahan kerusakan mekanik terutama motor penggerak dan pengembangan sensor line follower yang lebih adaptif terhadap warna lantai. Pada penelitian [17] telah dikembangkan rancang bangun robot line follower sebagai pengantar makanan, cara kerja robot ini adalah mengantarkan makanan dari suatu tempat ke tempat tujuan yang dalam hal ini tujuannya adalah sebuah meja dengan mengatur alamat mejanya berdasarkan setting jumlah simpangan garis yang dihitung oleh sensor foto dioda. kekurangan dari rancang bangun ini adalah belum bisa start otomatis setelah barang yang akan diantar sudah berada diposisinya selain itu hanya bisa berjalan pada lantai dengan warna putih dan garis warna hitam. Pada prototype Mesin Pengantar Barang Otomatis menggunakan load cell berbasis robot line follower saat dioperasikan mode otomatis prototype akan berjalan otomatis saat benda yang akan diantar sudah berada diposisinya dengan syarat benda sudah memenuhi atau melebihi setting beban dan kurang dari beban maksimum. Selain itu juga bisa dioperasikan pada warna lantai dan garis yang berbeda-beda dengan syarat antara lantai dan garis memiliki warna dengan kontras yang berbeda.

Pada penelitian [18] tentang pengenalan warna lantai dan garis dijelaskan tentang penggunaan metode DFT untuk menyesuaikan kondisi pencahayaan sekitar sensor selain itu penelitian ini hanya diuji pada lantai berwana hijau dan garis putih. Sedangkan pada penelitian prototype Mesin Pengantar Barang Otomatis menggunakan load cell berbasis robot line follower tidak menyesuaikan kondisi pencahayaan di sekitarnya akan tetapi membuat kondisi pencahayaan sekitar menjadi ideal dengan cara menutupi sensor dan LED sehingga meminimalisir cahaya luar yang masuk. Cara ini lebih efektif karena ada tempat yang kondisi cahayanya tidak terkontrol seperti saat kondisi luar ruangan pada siang hari yang cerah untuk pengujianya dilakukan pada semua warna dari gelap hingga warna terang dengan warna standar kertas asturo.

Penelitian lain yang sejenis, robot line follower digunakan sebagai mesin pengangkut penumpang otomatis sebagaimana robot line follower menggantikan peranan operator atau sopir sebagai pengantar penumpang [11]. Alat tersebut juga diintegrasikan dengan sensor ultra sonik untuk mendeteksi obyek di depan sebagai pemicu pengereman otomatis serta dilengkapi bluetooth sebagai komunikasi dengan perangkat android, namun kekurangan yang ada pada pengembangan tersebut sebagai alat angkut barang adalah kemampuan dalam mendeteksi berat beban untuk mencegah kerusakan dan keselamatan para penumpang. Kesamaan penelitian [11] dengan prototype Mesin Pengantar Barang Otomatis menggunakan load cell berbasis robot line follower adalah penggunaan sistem kerja robot line follower sebagai otomatisasi akan tetapi sudah dilengkapi dengan kemampuan menghitung berat beban untuk mencegah kerusakan mekanik dan keselamatan pengguna akibat berat beban yang berlebih.

Penelitian lain tentang robot line follower adalah robot line follower dilengkapi dengan kamera yang digunakan untuk menangkap gambar obyek kemudian dilakukan poses (image processing) [19]. Fungsi penambahan fitur kamera adalah membaca kode atau huruf yang terdapat objek untuk menentukan destinasi. Kekurangan alat ini sebagai alat pengangkut barang adalah juga belum terpasang alat pengukur berat beban. Pada penelitian [19] digunakan LED warna biru dengan asumsi lebih adaptif dengan perubahan warna lantai akan tetapi belum diuji dengan warna lantai yang berbeda-beda. Sedangkan pada prototype mesin pengantar barang menggunakan LED warna putih dan sudah diuji dengan perubahan warna dengan kertas asturo yang hasilnya cukup baik dan adaptif dalam membedakan warna lantai dan garis.

\section{IV.PENUTUP}

\section{A. Simpulan}

1. Prototype mesin pengantar barang hasil penelitian ini menggunakan load cell berbasis robot line follower yang mampu bergerak dengan mode manual maupun otomatis dan dapat menghitung berat beban serta mencegah motor untuk berputar saat beban melebihi beban maksimum.

2. Simpangan pembacaan sensor load cell terhadap timbangan pembanding tipe SF-400 sebesar 0,117\% yang disebabkan oleh beberapa faktor diantaranya adanya tegangan offset dan noise pada pengukuran rangkaian pengkondisi sinyal serta desain mekanik yang hanya terdiri dari satu sensor atau juga dimungkinkan kesalahan yang terjadi disebabkan oleh tingkat ketelitian timbangan pembanding SF-400 yang memiliki nilai ketelitian 1 gram. Akan tetapi sensor load cell tetap mampu mendeteksi berat beban untuk gerak otomatis dan mencegah kerusakan motor dengan mencegah untuk berputar saat berat melebihi beban maksimum.

3. Sensor foto dioda mampu membaca garis dengan warna dasar atau lantai yang berbeda. Prototype mampu membaca garis pada warna lantai dengan selisih tegangan terkecil 0,44 Volt atau jika dikonversi pada data ADC sebesar 20 level dan terjadi error jika selisih tegangan kurang dari 0,4 Volt atau jika dikonversi pada data ADC kurang dari 18.

\section{B. Saran}

Penelitian dapat dilakukan pengembangan khususnya untuk mengembangkan kode program agar dapat melakukan kalibrasi warna lantai secara otomatis sehingga lebih adaptif terhadap perubahan warna lantai yang tentunya dengan data ADC yang berbeda. Kemudian dapat dilakukan uji skalatis apakah prototype mampu menjadi model alat pengangkat barang dengan skala lebih besar. 


\section{REFERENSI}

[1] Peraturan Menteri Perindustrian Republik Indonesia (PERMENPERIN) Nomor: 11/M-IND/PER/3/2014 Pasal 1 Ayat 1. Program Restrukturisasi Mesin dan/ atau Peralatan Indstri kecil dan menengah.

[2] H. L. Suwarno, Sembilan Fungsi Saluran Distribusi : Kunci Pelaksanaan Kegiatan, Jurnal Managemen 6(1), pp. 79-87, 2006.

[3] P. Simanungkalit, R. Yasra, dan B. W. Widiodo, Perencanaan Sistem Perawatan Alat Angkat Kapasitas 5 Ton dengan Metode Preventive Maintenance (Studi Kasus Pt . Trikarya Alam) The Maintenance System Planning Of Lift Tool With Capacity 5 Ton Using Preventive Maintenance Method (Case Study Pt . Trikarya Alam), Profisiensi 4(1), pp. 47-57, 2016.

[4] Peraturan Menteri Tenaga Kerja Republik Indonesia Nomor:PER.05/MEN/1985 Pasal 73 ayat 2 Tentang Pesawat Angkat dan Angkut.

[5] T. D. Rawis, Perencanaan Biaya Keselamatan dan Kesehatan Kerja ( K3 ) pada Proyek Konstruksi Bangunan (Studi Kasus : Sekolah St . Ursula Kotamobagu), Jurnal Sipil Statik 4(4), pp. 241-252, 2016

[6] T. Santoso, Rancang Bangun Kualifikator Susu Sapi Berbasis Mikrokontroler, 2016.

[7] A. L. Khakim dan S. Purbawanto, Rancang Bangun Alat Timbang Digital Berbasis AVR Tipe Atmega32, Jurnal Teknik Elektro, 7(2), 7680, 2017.

[8] A. Z. Falani dan S. Budi, Robot Line Follower Berbasis Mikrokontroler Atmega 16 dengan Menampilkan Status Gerak Pada LCD. e-jurnal Narodroid 1(1), 2015
[9] O. Gumus, M. Topaloglu, dan D. Ozcelik, The Use of Computer Controlled Line Follower Robots in Public Transport, Procedia Computer Science, The Author(s), 102(August), pp. 202-208, 2016, doi: 10.1016/j.procs.2016.09.390.

[10] A. Nur, P. Sihombing, dan D. Sitompul, Prototipe Robot Line Follower untuk Simulasi Taksi Wisata Otomatis Kota Medan Menggunakan Algoritma Fuzzy, Jurnal USU pp. 2-7.

[11] C. Indriyanto, dan P. Sihombing, Implementasi Algoritma Fuzzy Logic Pada Robot Autopilot Line Follower Berbasis Implementasi Algoritma Fuzzy Logic pada Robot Autopilot Line Follower Berbasis Mikrokontroler ATMega32A (Studi Kasus : Miniatur Bus Lintas USU), Reserch Gate, 2016, doi: 10.13140/RG.2.2.16311.11688.

[12] Yultrisna, Rancang Bangun Robot Solving Maze Dengan Algoritma Depth, Jurnal Momentum 15(2), pp. 87-93, 2013.

[13] Datasheet HX711, 24-Bit Analog-to-Digital Converter (ADC) for Weigh Scales, AVIA Semiconductor, 2014

[14] H. Andrianto dan A. Darmawan, Arduino Belajar Cepat dan Pemrograman, Bandung : Informatika Bandung, 2016.

[15] N. A. Pratama dan T. Andrasto, Komunikasi Pada Robot Swarm Pemadam Api Menggunakan Protokol ModBus. Jurnal Teknik Elektro 6(2), 2013.

[16] Datasheet VNH2SP30, VNH2SP3O-E Automotive fully integrated $H$ bridge motor driver. www.st.com, pp. 1-33, 2013.

[17] D. A. N Janis, et al., Rancang Bangun Robot Pengantar Makanan Line follower. ejurnal teknik elektro dan komputer pp. 1-10, 2014.

[18] Ng, K. Hooi. et al., Adaptive Phototransistor Sensor for Line Finding, 41(Iris), pp. 237-243, 2012, doi: 10.1016/j.proeng.2012.07.168.

[19] K. A. Vignesh et al., Computer Vision Assisted Line Followin Robots, Procedia 38, pp. 1764-1772, 2012, doi: 10.1016/j.proeng.2012.06.215. 